\title{
Our experience in surgical treatment of spinal disc herniation
}

\author{
For citation: Bol', sustavy, pozvonočnik. 2019;9(3):199-204. doi: 10.22141/2224-1507.9.3.2019.178644
}

\begin{abstract}
Background. The purpose of the study was to evaluate the effectiveness of the transforaminal endoscopic microdiscectomy, to highlight the disadvantages and advantages of this method in comparison with traditional methods, based on the data obtained to determine the main indications and contraindications to this procedure. Materials and methods. One-hundred and ninety clinical records of the patients with lumbar spinal cord injuries were analyzed, which were treated at the Regional Centre of Orthopedics, Traumatology and Vertebrology "Rivne Regional Clinical Hospital" from April 2016 to April 2018. We performed a quantitative and qualitative assessment of pain syndrome by the Visual Analogue Scale of Pain (VAS); assessment of the quality of life by Oswestry Disability Index. Results. The use of transforaminal endoscopic microdiscectomy for the treatment of patients with spinal disk herniation confirmed the high efficiency of this technique. So, the international Oswestry Disability Index demonstrated in average $21.1 \%$ for the group in operated patients, which corresponds to a good result. The dynamics of the pain syndrome was estimated by VAS and its preoperative level was 8.5 scores, and in 6 months after the operation - 1.5 with the predominance of lumbalgia, and with the almost complete absence of root pain. This technique makes it possible to enter the endoscope into the vertebral canal under the local anaesthesia minimally invasive and under visual control to decompress the nerve root by removing the hernial bulging. However, the technique is not universal and cannot be applied to all patients. Conclusions. Considerable practical experience has shown that the surgeon can meet certain technical difficulties in cases of cranial or caudal migration of sequestration, in some cases access to the level of $L_{5}-S_{1}$ is difficult due to the high position of the iliac crest. However, with the correct indications, this technique allows solving the problem of the radicular syndrome in a short time.
\end{abstract}

Keywords: herniated disc; endoscopic microdiscectomy; lumbar osteochondrosis

\section{Introduction}

Surgical methods of treating intervertebral disk herniation at the lumbar spine change one another in a rapid succession. Although an open microdiscectomy is considered a 'gold standard' in surgery, recently there are many new methods whose inventors are trying to minimize the traumatic effect of surgery retaining its radical character. In early 1990s, an alternative method of transforaminal endoscopic microdiscectomy (ETM) was suggested [1-6]. Surgeons started to use two principal accesses - lateral (Richard Wolf) and posterolateral (JoyMax, Thesyss, MaxMore).

Most authors [4-6], along with us, prefer the posterolateral access due to a range of advantages: possibility of a partial facet resection enables the surgeon to enlarge the endoscopic space and reduce the extent of lateral stenosis, as well as to perform a partial revision of an interbody space; while the purely lateral approach allows resecting but the free sequesters from a canal. If the surgeons have been treating this method skeptically for a long time, nowadays the adherents of transforaminal endoscopic microdiscectomy are numerous, and their opinion is supported by many reports on the significant advantages of this method over an open surgery [7-10].

Furthermore, a number of surgeons do not restrict themselves to a proper microdiscectomy; instead they opt for an endoscopic surgery to remove facet joint cysts [11] and to treat various stenosis forms [12-15].

The purpose of the study was to evaluate the effectiveness of the transforaminal endoscopic microdiscectomy, to highlight the disadvantages and advantages of this method in comparison with the traditional methods, to determine the main indications and contraindications for this procedure, taking into account the data obtained.

C) 2019. The Authors. This is an open access article under the terms of the Creative Commons Attribution 4.0 International License, CC BY, which allows others to freely distribute the published article, with the obligatory reference to the authors of original works and original publication in this journal.

Для кореспонденції: Фіщенко Яків Віталійович, доктор медичних наук, провідний науковий співробітник відділу реабілітації, ДУ «|нститут травматології та ортопедії НАмН України», вул. Бульварно-Кудрявська, 27, м. Київ, 01601, Україна; e-mail: fishchenko@gmail.com; контактний тел.: +380 (50) 3808725.

For correspondence: lakiv Fishchenko, MD, PhD, Leading Research Fellow at the Department of spinal surgery, State Institution "Institute of Traumatology and Orthopaedics of the NAMS of Ukraine", Bulvarno-Kudriavska st., 27, Kyiv, 01601, Ukraine; e-mail: fishchenko@gmail.com; phone: +380 (50) 3808725.

Full list of author information is available at the end of the article. 


\section{Materials and methods}

190 medical records of patients with lumbar intervertebral disk herniation were analyzed. The patients were treated at the "Rivne Regional Clinical Hospital", the Regional Center of Orthopedics, Traumatology and Vertebrology, from 04.2016 to 04.2018. Prior to the surgery, all the patients underwent MRI or CT of lumbar spine, functional X-rays and general clinical examinations.

Among the indications for surgery there were: ineffective conservative treatment of spinal compression syndrome during 6-8 weeks, cauda equina syndrome, acute foot drop (paresis), and progressive neurological symptoms attending the conservative treatment.

The Table presents distribution of patients according to the hernia localization (by the MRI data). For instance, $120(63,1 \%)$ patients had a hernia at the level of $\mathrm{L}_{4}-\mathrm{L}_{5}, 50$ $(26,2 \%)$ patients had it at the level of $\mathrm{L}_{5}-\mathrm{S}_{1}, 3(1,6 \%)$ patients - at the level of $\mathrm{L}_{3}-\mathrm{L}_{4}, 10(5,3 \%)$ patients at all 3 levels: $\mathrm{L}_{4}-\mathrm{L}_{5}$ and $\mathrm{L}_{5}-\mathrm{S}_{1}, 2(1,1 \%)$ patients - at the level of $\mathrm{L}_{1}-\mathrm{L}_{2}$ and $5(2,7 \%)$ patients - at the level of $\mathrm{L}_{2}-\mathrm{L}_{3}$. Distribution of patients according to the hernia localization within the spinal canal is given in Table 1.

\section{Surgery technique}

Surgery was performed with MaxMore surgical instruments by T. Hoogland. The 'outside in' technique was applied [4-6] (Fig.1).

With patient lying prone, the surgeon marks out the dilatators' access trajectory on his/her stomach. At $\mathrm{L}_{5}-\mathrm{S}_{1}$, the surgeon retreated $12-14 \mathrm{~cm}$ from the median, at $\mathrm{L}_{4}-\mathrm{L}_{5}-10$ $12 \mathrm{~cm}$, and at $\mathrm{L}_{1}-\mathrm{L}_{2}$ and $\mathrm{L}_{3}-\mathrm{L}_{4}-8-10 \mathrm{~cm}$. to determine the angle, trajectory was drawn through the tip of lateral facet and hernia base. After a local anesthesia with a $2 \%$ lidocaine solution, spinal needle was put at the tip of lateral facet (Fig. 2a). Conduit pin was passed along the needle (Fig. 2b), softly along with tissue dilatators, Tom- Shidi needle and bone expanders from 4,5 to $9 \mathrm{~mm}$ in succession (Fig. 2c). All the steps were monitored by electronic-optical transformer in 2 projections (Fig. 2d).

After a partial resection of lateral facet, the cannula was inserted in a transforaminal projection (Fig. 3a); later along this cannula an endoscope was put inside the patient's body (Fig. 3b). A continuous flow of sterile saline fluid, previously warmed to the normal body's temperature, was provided under the $80 \mathrm{~mm}$ pressure of water gauge. On identifying the protrusion, the surgeons removed it with a microronger (Fig. 3c), while the larger sequesters not fitting the endoscope's canal were evacuated together with an optical tool (Fig. 3d).
In order to achieve a complete removal of minor disc particles, epidural compounds and dissociated posterior longitudinal ligament, we've been using Triger-Flex, radiofrequency electrode connected to a radio-frequency generator with an operative temperature of up to 42 degrees Centigrade at its tip. Low-temperature coagulation reduced surrounding tissues' response to the intervention and prevented epidural fibrosis. Complete root decompression resulted in a dura mater and root pulsation, considered a positive sign (Fig.4).

In a follow-up period, we've performed a control MRI examination to verify the complete hernia removal (Fig.5).

\section{Results and discussion}

According to the international Oswestry life quality questionnaire, mean value for the operated-on patients was $21,1 \%$, corresponding to a good result. Vertebral pain syndrome and its dynamics were evaluated by means of VAS: in the post-op period it amounted to 8,5 points, while in the 6-month follow-up period - 1,5 points. Lumbar pain predominated; root pain was almost completely absent.

An average 'bed-day' index was 3 days; verticalization took place 2-3 hours after surgery. In the post-op period, patients were recommended to take the non-steroid antiinflammatory drugs (NSAIDs), Gabapentini and peripheral muscle relaxant drugs for up to 7 days. Neurotropic therapy was recommended for 1 month.

We should mention the following technical difficulties and complications we were facing:

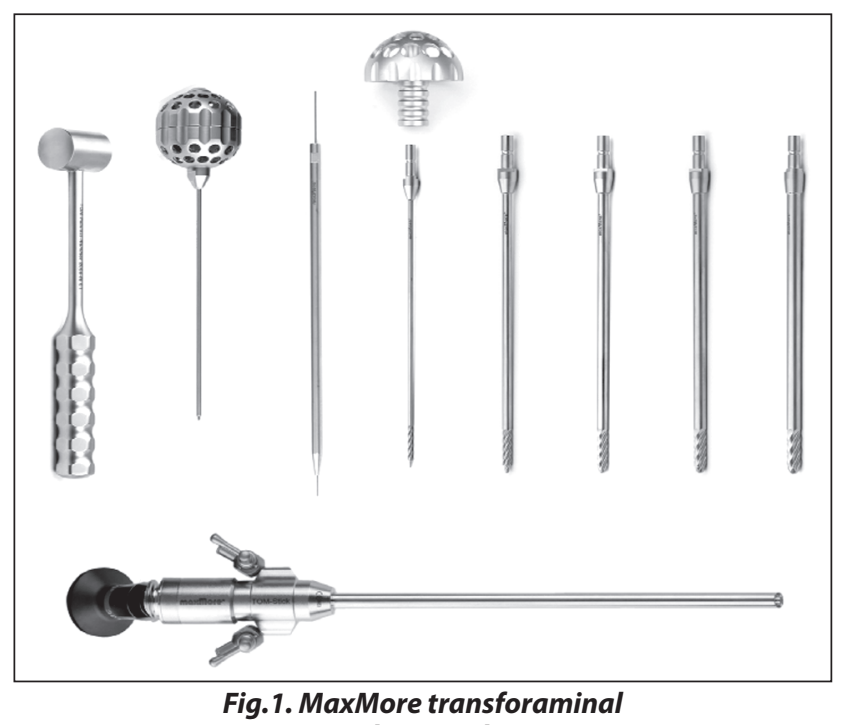
endoscopic kit

Table 1. Distribution of patients according to the hernia localization

\begin{tabular}{|c|c|c|c|c|c|c|}
\hline Localization Level & $L_{1}-L_{2}$ & $L_{2}-L_{3}$ & $L_{3}-L_{4}$ & $L_{4}-L_{5}$ & $\mathrm{~L}_{5}-\mathrm{S}_{1}$ & $\mathrm{~L}_{4}-\mathrm{L}_{5}-\mathrm{S}_{1}$ \\
\hline Median & & 2 & 1 & 18 & 5 & \\
\hline Paramedian & 2 & 3 & 2 & 90 & 40 & 7 \\
\hline Foraminal & & & & 10 & 5 & 3 \\
\hline Extraforaminal & & & & 2 & & \\
\hline Total & $2(1,1 \%)$ & $5(2,7 \%)$ & $3(1,6 \%)$ & $120(63,1 \%)$ & $50(26,2 \%)$ & $10(5,3 \%)$ \\
\hline
\end{tabular}




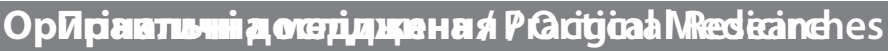

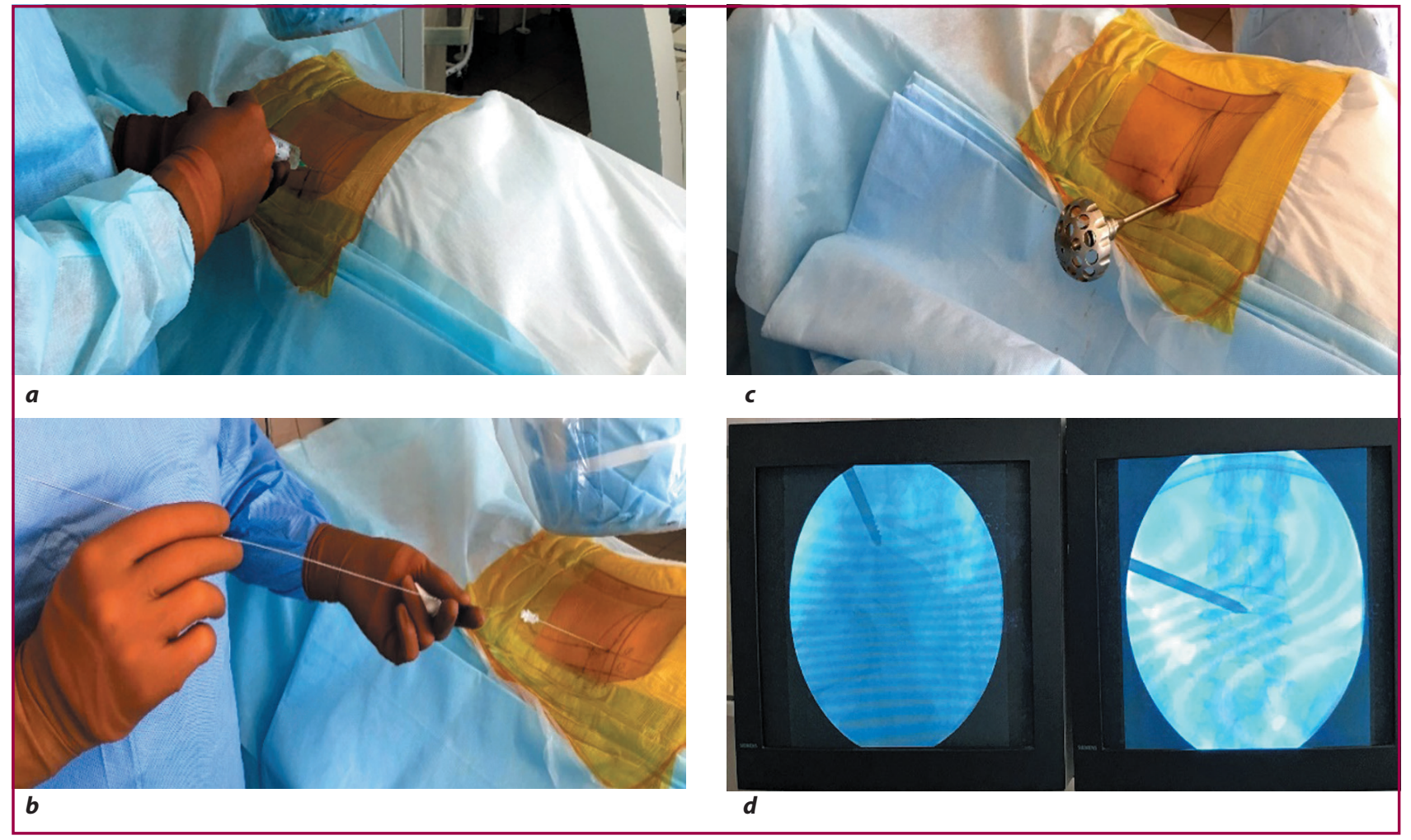

Fig. 2. Steps of the transforaminal access.

Note: $a$ - marking out the entry trajectory and local anesthesia; $b$ - insertion of conduit pin; $c$ - insertion of bone expanders; $d$ monitoring by electronic-optical transformer

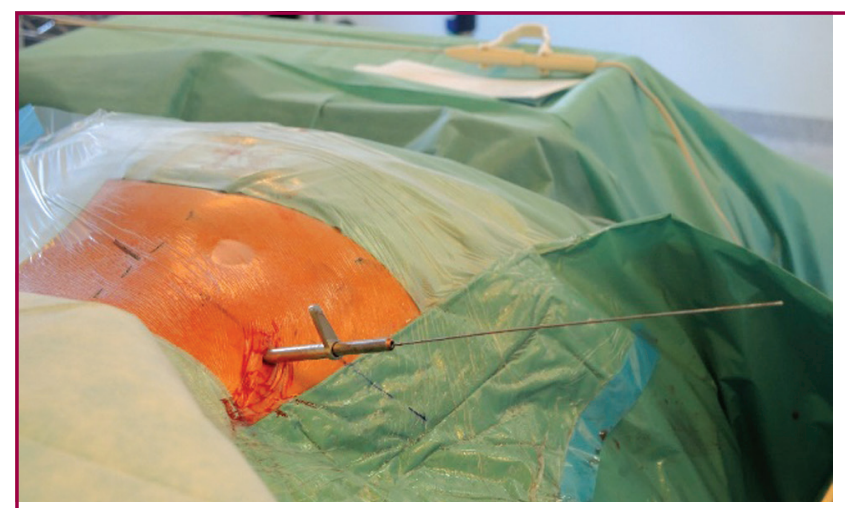

$a$



$\boldsymbol{b}$
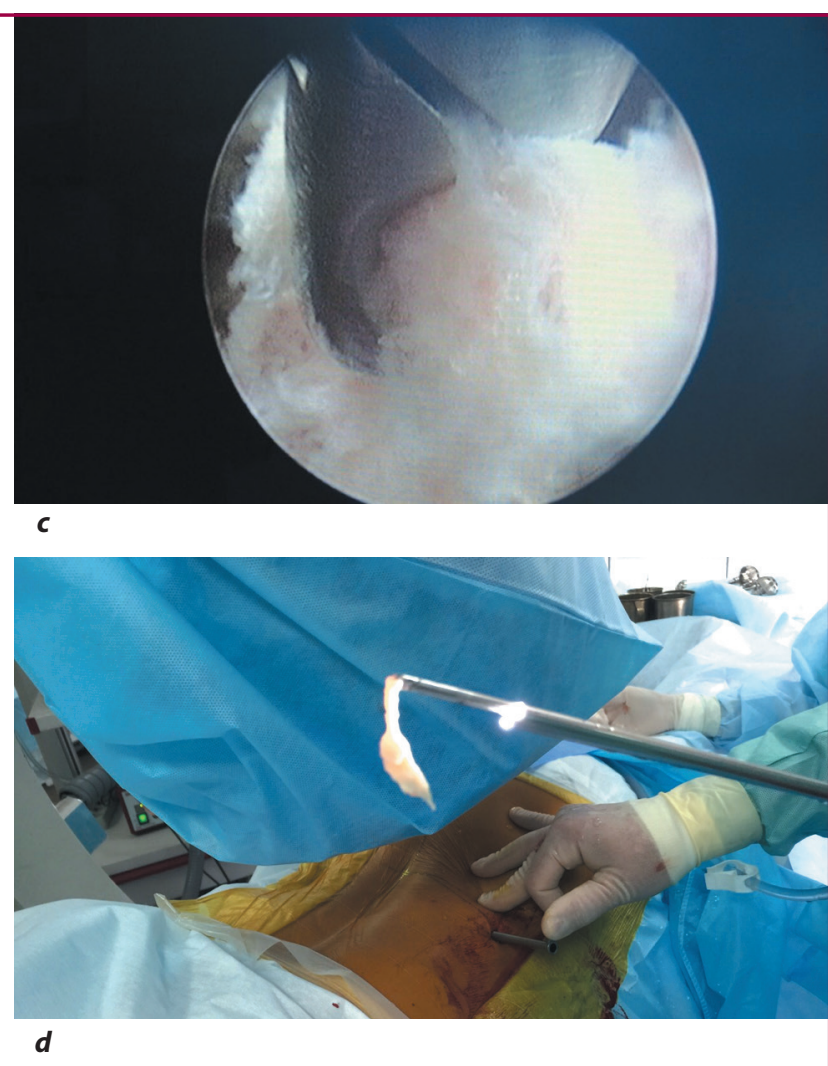

Fig. 3. Steps of transforaminal endoscopic microdiscectomy (ETM)

Note: $a$ - insertion of a cannula; $b$ - insertion of endoscope with a continuous flow of saline fluid; $c$ - identifying and removing the protrusion; $d$ - evacuation of a larger sequester 
1. At the initial stages of acquiring the technique, 6 $(3,1 \%)$ patients did not get a complete protrusion evacuation due to the performers' lack of experience and major sequesters' migration along the canal. It prompted a repeat intervention.

2. In $5(2,6 \%)$ asthenic patients at the level of L5-S1, transforaminal and peripheral intervention was impossible due to an elevated position of ilium ridge. In those cases open surgery was performed.

3. In $11(5,8 \%)$ patients, the hernia recurred after 6 months. We attribute this reccurrence to the fact that the transforaminal endoscopic microdiscectomy does not involve a radical revision and curettage of disc cavity, potentially leading to a migration of loose interbody elements

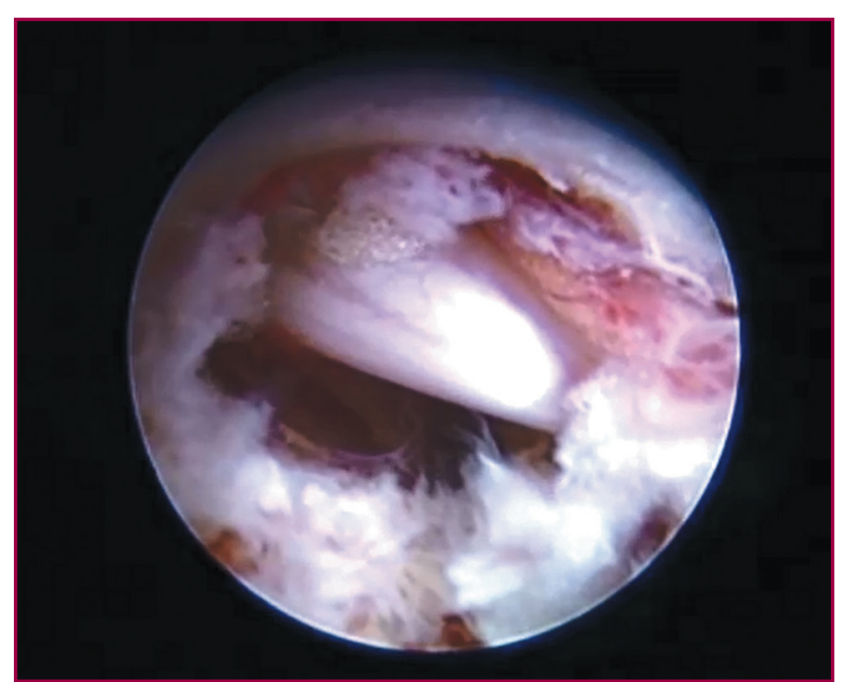

Fig.4. Visualization of a nerve root after a complete hernia removal into the spinal canal. According to various reports [2, 3], disc hernia reccurrence happens in 8 to $9 \%$ of cases, following the open microdiscectomy. This number is significantly lower than our findings - 9,9\% (6,5\% - recurrence and 3,4\% - incomplete evacuation of protrusion). The remaining $168(88,4 \%)$ patients had a positive dynamic of neurological dificit recovery.

4. In $2(1,1 \%)$ patients with signs of initial instability, after 6 to 8 months after surgery instability increased, marked by the back pain intensification, even without a neurological deficit. It required a transpedicular fixation.

5. Aseptic spondilodiscitis developed in $3(1,57 \%)$ patients. Its progression was arrested by the traditional medication.

6. In $2(1,1 \%)$ patients, intrasurgical damage of dura mater occurred, presumably due to present epidural adhesive process caused by a long disease and pronounced central spinal stenosis. To prevent the liquorrhea, we used the TachoComb sponge and put a deep suture on the wound. This complication did not reflect on the surgery outcomes in any noticeable way; its percentage being as low as with a traditional microdiscectomy.

In light of the above mentioned facts, we may outline the principal indications for the transforaminal endoscopic microdiscectomy (ETM):

- intervertebral disk herniation at any lumbar spine segment, root compression syndrome not responding to the conservative treatment during 6-8 weeks;

- acute foot drop (paresis);

- cauda equina syndrome.

Among the contraindication we find:

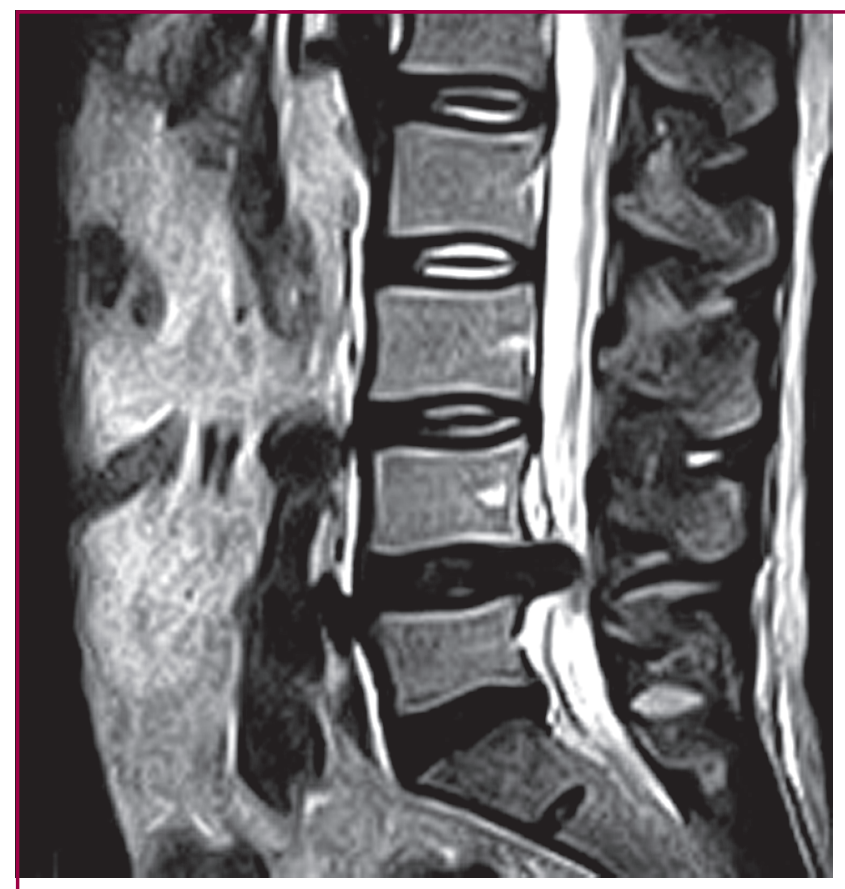

a



Fig.5. MRI photo prints of patient M., 44 years old;

$a$ - before and $b$ - after $a$ transforaminal endoscopic microdiscectomy 
- elevated position of ilium ridge, ruling out the transforaminal access at the level of L5-S1;

- instability of spinal and locomotor segment at the operated level;

- pronounced central spinal stenosis;

- remote cranial or caudal migration of loose sequesters.

\section{Conclusions}

Transforaminal endoscopic microdiscectomy (ETM) was proved highly effective in treatment of intervertebral disk herniations. According to the international Oswestry life quality questionnaire, mean value for the operatedon patients was $21,1 \%$, corresponding to a good result. Vertebral pain syndrome and its dynamics were evaluated by means of VAS: in the post-op period it amounted to 8,5 points, while in the 6 -month follow-up period $-1,5$ points. Lumbar pain predominated; root pain was almost completely absent.

Performing this intervention on patients with intervertebral disk herniae revealed the following advantages: minimal damage of soft tissues and minimal contact with nerve structures; quick post-intervention recovery reduces the work incapacitation term; unlike the traditional electrocoagulation, coagulation of epidural vessels with a radio-frequency electrode of a $42{ }^{\circ} \mathrm{C}$ operative temperature reduced epidural fibrosis risk; optimal visualization of intracranial structures with an optic enlargement reduces the nerve root damage risk; direct access to the extrusion via the natural foraminal opening; minimal infection-related complication risk.

Conflicts of interests. Authors declare the absence of any conflicts of interests and their own financial interest that might be construed to influence the results or interpretation of their manuscript.

\section{References}

1. Kambin P, editor. Arthroscopic Microdiscectomy: Minimal Intervention in Spinal Surgery. Baltimore: Urban \& Schwarzenberg; 1991. 148 p.

2. Caspar W. A New Surgical Procedure for Lumbar Disc Herniation Causing Less Tissue Damage Through a Microsurgical Approach. In: Wüllenweber R, Brock M, Hamer J, Klinger M, Spoerri O, editors. Lumbar Disc Adult Hydrocephalus; 1977. Berlin, Heidelberg: Springer; 1977. 74-77 pp. https://doi.org/10.1007/978-3-642-66578-3_15.

3. Kambin P. History of disc surgery. In: Kambin P, editor. Arthroscopic Microdiscectomy: Minimal Intervention in Spinal Surgery. Baltimore: Urban \& Schwarzenberg; 1991. 3-8 pp.

4. Hoogland T. Transforaminal endoscopic discectomy with foraminoplasty for lumbar disc herniation. Surg Tech Orthop Traumatol. 2003;40(40):55-120.
5. Hoogland T, Scheckenbach C. Die endoskopische transforminale diskektomie bei lumbalen bandscheibenforfallen. Orthop Prax. 1998;(34):352-355.

6. Hoogland T, Schubert M, Miklitz B, Ramirez A. Transforaminal posterolateral endoscopic discectomy with or without the combination of a low-dose chymopapain: a prospective randomized study in 280 consecutive cases. Spine (Phila Pa 1976). 2006 Nov 15;31(24):E890-7. https://doi. org/10.1097/01.brs.0000245955.22358.3a.

7. Rutten S. Endoscopic lumbar disc surgery. In: Vieweg U, Grochulla F, editors. Manual of Spine Surgery. Berlin, Heidelberg: Springer-Verlag; 2012. 303-308 pp. https://doi. org/10.1007/978-3-642-22682-3 43.

8. Ahn Y, Lee S. Outcome predictors of percutaneous endoscopic lumbar discectomy and thermal annuloplasty for discogenic low back pain. Acta Neurochir (Wien). 2010 Oct;152(10):1695-702. https://doi.org/10.1007/s00701-0100726-2.

9. Wang H, Huang B, Li C, et al. Learning curve for percutaneous endoscopic lumbar discectomy depending on the surgeon's training level of minimally invasive spine surgery. Clin Neurol Neurosurg. 2013 Oct;115(10):1987-91. https:// doi.org/10.1016/j.clineuro.2013.06.008.

10. Lee S, Kim SK, Lee SH, et al. Percutaneous endoscopic lumbar discectomy for migrated disc herniation: classification of disc migration and surgical approaches. Eur Spine J. 2007 Mar;16(3):431-7. https://doi.org/10.1007/s00586-0060219-4.

11. Komp M, Hahn P, Oezdemir S, et al. Operation of lumbar zygoapophyseal joint cyst using a full - endoscopic inter-laminar and transforaminal approach: prospective 2-year results of 74 patients. Surg Innov. 2014 Dec;21(6):605-14. https://doi.org/10.1177/1553350614525668.

12. Komp M, Hahn P, Oezdemir S, et al. Bilateral decompression of lumbar central stenosis using the full-endoscopic inter-laminar technique: a prospective, randomized, controlled study. Pain Physician. 2015 Jan-Feb;18(1):61-70.

13. Rutten S, Komp M, Oezdemir S. Current status of full endoscopic techniques in the surgical treatment of disc herniation and spinal canal stenosis. Chines Journal of Bone and Joint. 2014;(8): 571-584.

14. Ruetten S, Komp M, Hahn P, Oezdemir S. Decompression of lumbar lateral spinal stenosis: full-endoscopic, interlaminar technique. Oper Orthop Traumatol. 2013 Feb;25(1):31-46. https://doi.org/10.1007/s00064-012-0195-2. (in German).

15. Rutten S. Endoscopic disk and decompression surgery. In: Haertl R, Korge A, editors. Minimally invasive Spine Surgery. Stuttgard, New York: Thieme; 2012. 315-330 pp. https:// doi.org/10.1055/b-0034-92566.

16. Ruetten S, Komp M, Merk H, Godolias G. Recurrent lumbar disc herniation after conventional discectomy: a prospective, randomized study comparing full-endoscopic interlaminar and transforaminal versus microsurgical revision. J Spinal Disord Tech. 2009 Apr;22(2):122-9. https://doi. org/10.1097/BSD.0b013e318175ddb4.

Received 09.06.2019

Revised 25.06.2019

Accepted 12.07.2019

\section{Information about authors}

Valentyn Piontkovskyi, PhD, Head of the Department of orthopedics, traumatology and vertebrology, Rivne Regional clinical hospital, Rivne, Ukraine; e-mail: pion_val@ukr.net; ORCID iD: http: //orcid.org/0000-0002-0080-3327

la.V. Fishchenko, MD, PhD, Leading Research Fellow at the Department of spinal surgery, State Institution "Institute of Traumatology and Orthopaedics of the NAMS of Ukraine", Kyiv, Ukraine; e-mail: fishchenko@gmail.com; ORCID iD: http://orcid.org/0000-0001-7446-0016 
Піонтковський В.К. ${ }^{1}$, Фіщенко Я.В. ${ }^{2}$

'КЗ «Рівненська обласна клінічна лікарня», м. Рівне, Україна

${ }^{2}$ ДУ «Інститут травматології та ортопедії НАМН України», м. Київ, Україна

\section{Наш досвід хірургічного лікування гриж міжхребцевих дисків}

Резюме. Мета дослідження: оцінити ефективність трансфорамінальної ендоскопічної мікродискектомії, виділити недоліки та переваги даного методу порівняно з традиційними методиками, на підставі отриманих даних визначити основні показання та протипоказання до проведення даної процедури. Матеріали та методи. Проаналізовано 190 історій хвороби пацієнтів з грижами поперекового відділу хребта, які лікувалися в Обласному центрі ортопедії, травматології та вертебрології К3 «Рівненська обласна клінічна лікарня» з 04.2016 по 04.2018. Проводилася кількісна та якісна оцінка больового синдрому за візуальною аналоговою шкалою болю (ВАШ), оцінка якості життя за анкетою Oswestry. Результати. Застосування трансфорамінальної ендоскопічної мікродискектомії в лікуванні пацієнтів з грижами міжхребцевих дисків (МХД) підтвердило досить високу ефективність даної методики. Так, за даними міжнародного опитувальника якості життя Oswestry, середній показник у групі прооперованих становив $21,1 \%$, що відповідає доброму результату. Відмічено позитивну динаміку больового синдро- му за ВАШ: у передопераційному періоді цей показник становив 8,5 бала, а через 6 місяців після операції - 1,5 бала з переважанням люмбалгії та майже повною відсутністю корінцевого болю. Дана методика дозволяє малоінвазивно під місцевою анестезією ввести ендоскоп у хребетний канал і під візуальним контролем провести декомпресію нервового корінця шляхом видалення грижового випинання. Однак методика не $є$ універсальною та не може бути застосована в усіх пацієнтів. Висновки. Значний практичний досвід показав, що хірург може зустрітися з певними технічними труднощами у випадках краніальної або каудальної міграції секвестру грижі МХД, у низці випадків доступ на рівні $\mathrm{L}_{5}-\mathrm{S}_{1} \in$ складним через високе розташування гребеня клубової кістки. Але при наявності правильних показань методика мікродискектомії дозволяє в короткий термін ефективно лікувати пацієнтів 3 компресійним корінцевим синдромом.

Ключові слова: грижа диска; ендоскопічна мікродискектомія; поперековий остеохондроз

Пионтковский В.К.' , Фищенко Я.В. ${ }^{2}$

'КУ «Ровенская областная клиническая больница», г. Ровно, Украина

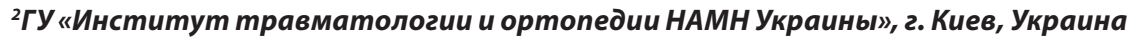

\section{Наш опыт хирургического лечения грыж межпозвоночных дисков}

Резюме. Цель исследования: оценить эффективность трансфораминальной эндоскопической микродискэктомии, выделить недостатки и преимущества данного метода по сравнению с традиционными методиками, на основе полученных данных определить основные показания и противопоказания к данной процедуре. Материалы и методы. Проанализировано 190 историй болезни пациентов с грыжами поясничного отдела позвоночника, которые лечились в Областном центре ортопедии, травматологии и вертебрологии «Ровенская областная клиническая больница» с 04.2016 по 04.2018. Применялись количественная и качественная оценка болевого синдрома по визуальной аналоговой шкале боли (ВАШ), оценка качества жизни по анкетированию Oswestry. Результаты. Применение трансфораминальной эндоскопической микродискэктомии в лечении пациентов с грыжами межпозвоночных дисков подтвердило достаточно высокую эффективность данной методики. Так, в соответствии с международным опросником качества жизни Oswestry, средний показатель по группе среди прооперированных составил $21,1 \%$, что соответствует хорошему результату. Динамика болевого синдрома оценивалась по ВАШ и в предоперационном периоде составляла 8,5 балла, а через 6 месяцев после операции - 1,5 балла с преобладанием люмбалгии и с почти полным отсутствием корешковой боли. Данная методика позволяет малоинвазивно под местной анестезией ввести эндоскоп в позвоночный канал и под визуальным контролем провести декомпрессию нервного корешка путем удаления грыжевого выпячивания. Однако методика не является универсальной и не может быть применена у всех пациентов. Выводы. Значительный практический опыт показал, что хирург может встретиться с определенными техническими трудностями в случаях краниальной или каудальной миграции секвестра, в ряде случаев доступ на уровне $\mathrm{L}_{5}-\mathrm{S}_{1}$ затруднен из-за высокого расположения гребня подвздошной кости. Но при наличии правильных показаний эта методика позволяет в короткие сроки решить проблему компрессионного корешкового синдрома.

Ключевые слова: грыжа диска; эндоскопическая микродискэктомия; поясничный остеохондроз 